\title{
PEMANFAATAN ECENG GONDOK UNTUK MENURUNKAN KADAR DETERJEN DI DALAM AIR
}

\author{
Dedi Putri Purwati, Ferry Kriswandana, Bambang Sunarko
}

\begin{abstract}
Detergent is included as chemical characteristic of the wastewater in the form of organic compound that has negative impact on the enviroment and human health. Phytoremediation can be used to reduce level of detergent by using the water hyacinth plant as abssorbent. The purpose of this research is to use water hyacinth to reduce level of detergent in water.

This is a pre-experimental research with one group pretest-posttest approach. Data collection was conducted by checking detergent level for a contact time as many as 31 samples. Furthermore, the data was analyzed descriptively by using tabulation.

The highest percentage of decrease in detergent level based on the amount of water hyacinth was in the $6^{\text {th }}$ day with 6 hyacinth by $70.08 \%$. In this research, it is advisable to raw water companies to use water hyacinth in reducing level of detergent in water. Other researchers are suggested to increase the amount of water hyacinth and extend contact time by performing the same processing. To add detergent, it needs to take into account the initial detergent concentration.
\end{abstract}

Keywords : wastewater, water hyacinth, detergent level

\section{PENDAHULUAN}

Air limbah yang di buang begitu saja ke badan perairan dalam waktu yang lama dapat menimbulkan pencemaran lingkungan (Yunarsih, Ni Made, 2013). Salah satu badan air yang dimanfaatkan untuk kelangsungan hidup dan perekonomian masyarakat adalah Sungai Kali Surabaya. Fungsinya sungai tersebut adalah sebagai pengambilan air irigasi, PDAM, Industri dan pengendalian banjir (Kusnan, 2012). Penanganan yang sudah dilakukan oleh Badan Lingkungan Hidup Kota Surabaya berupa jalan pembersihan dari sampah dan pengerukan endapan sungai. Dan menurut kepala Badan Lingkungan Hidup Surabaya Musdiq Ali Suhudi, 2014 menyampaikan yang banyak mencemari pesisir adalah deterjen yang berasal dari limbah domestik sebanyak 75 persen (Gumilang, Guslan, 2014).

Hidayati, Nuril. (2005:35) teknik fitoremediasi telah dibuktikan lebih mudah diaplikasikan dengan biaya lebih rendah. Salah satu tanaman yang dapat digunakan dalam proses fitoremediasi adalah eceng gondok. Eceng gondok dapat dimanfaatkan sebagai material penyerap (adsorben) bahan berbahaya bagi lingkungan, dikarenakan kandungan selulosa sebesar $72,63 \%$ (Sri Lestari, 2012). Dan selama ini eceng gondok hanya dimanfaatkan sebagai kerajinan tangan baik pada industri rumah tangga maupun mebel (Putera, dkk, 2012).

\section{TUJUAN}

Penelitian ini bertujuan memanfaatkan eceng gondok untuk menurunkan kadar deterjen di dalam air.

\section{METODE PENELITIAN}

Jenis Penelitian

Penelitian ini merupakan pra eksperimen dengan rancangan penelitian adalah "one grup pretest-posttest design". Pemeriksaan ini dilakukan di laboratorium.

\section{Variabel Penelitian}

Variabel bebas adalah tidak diberi perlakuan, perlakuan I (limbah dengan 2 eceng gondok), perlakuan II (limbah dengan 4 eceng gondok) dan perlakuan III (limbah dengan 6 eceng gondok). Untuk variabel terikat adalah penurunan kadar deterjen dalam air. Dan variabel pengganggu adalah $\mathrm{pH}$ dan suhu.

\section{Analisis Data}

Dalam penelitian ini terdapat 31 data yang didapat dari hasil uji di laboratorium, kemudian data tersebut dianalisis secara deskriptif. 
HASIL PENELITIAN

1. Kadar Deterjen Sebelum Diberi Eceng Gondok Berdasarkan Waktu Kontak

Untuk hasil pemeriksaan laboratorium tentang kadar deterjen selama waktu kontak nol hari sebesar 141.25 ppm, hari ke-2 sebesar 141.16 ppm, hari ke-4 sebesar 141.09 ppm dan hari ke-6 sebesar 140.88 ppm.

2. Kadar Deterjen Setelah Diberi Eceng Gondok Berdasarkan Waktu Kontak

Berdasarkan hasil pemeriksaan laboratorium pada perlakuan I, bahwa rata-rata kadar deterjen hari ke 0 kadar deterjen sebesar 141.25 ppm, hari ke-2 kadar deterjen sebesar 140.10 ppm, hari ke-4 kadar deterjen sebesar 138.43 ppm dan hari ke-6 kadar deterjen sebesar 134.06 ppm. Pada perlakuan II rata-rata kadar deterjen hari ke-2 kadar deterjen sebesar 139.17 ppm, hari ke-4 kadar deterjen sebesar 132.62 ppm dan hari ke-6 kadar deterjen sebesar 127.41 ppm. Pada perlakuan III rata-rata kadar deterjen hari ke-2 kadar deterjen sebesar 119.50 ppm, hari ke-4 kadar deterjen sebesar $89.21 \mathrm{ppm}$ dan hari ke-6 kadar deterjen sebesar 42.15 ppm. Dalam penelitian ini, $\mathrm{pH}$ terendah adalah 6.1 pada reaktor B1 hari ke-2. Sedangkan $\mathrm{pH}$ tertinggi adalah 7.2 pada reaktor A hari ke 6 . Suhu terendah dalam penelitian adalah $27^{\circ} \mathrm{C}$ pada reaktor B2 hari ke-2. Sedangkan suhu tertinggi adalah $30^{\circ} \mathrm{C}$ pada semua reaktor hari ke 0 .

3. Persentase Penurunan Kadar Deterjen Berdasarkan Perlakuan

Untuk persentase penurunan kadar deterjen pada hari ke 0 hingga hari ke-2 sebelum diberi eceng gondok menunjukkan nilai yang terkecil sebesar $0.06 \%$. Sedangkan persentase penurunan kadar deterjen terbesar yaitu pada hari ke-6 dengan menggunakan 6 eceng gondok, yaitu sebesar $70.08 \%$.

\section{PEMBAHASAN}

1. Kadar Deterjen Sebelum Diberi Eceng Gondok Berdasarkan Waktu Kontak

Di dalam penelitian ini hasil pemeriksaan sebelum diberi eceng gondok untuk hari ke 0 sampai hari ke6 terus mengalami penurunan kadar deterjen sebesar $0.21 \mathrm{ppm}$ atau $0.26 \%$. Sesuai dengan teori Said, Nusa Idaman, 2006:100 bahwa pada permukaan air, mikroorganisme diharapkan berperan untuk menguraikan deterjen secara biologis. Namun, perilaku mikroorganisme dalam penurunan deterjen di perairan tergantung dari struktur kimia penyusun deterjen.

2. Kadar Deterjen Setelah Diberi Eceng Gondok Berdasarkan Waktu Kontak

Dalam penelitian ini kadar deterjen awal $141.25 \mathrm{ppm}$ dengan semakin lamanya waktu kontak pada hari ke-6 dengan jumlah 2 eceng gondok kadar deterjen terus mengalami penurunan sebesar $4.37 \mathrm{ppm}$ atau $4.84 \%$. Hari ke-4 dengan jumlah 4 eceng gondok penurunan kadar deterjen sebesar $6.55 \mathrm{ppm}$ atau 9.56\% dan penurunan kadar deterjen yang paling banyak adalah hari ke- 6 dengan jumlah 6 eceng gondok menjadi 47.06 ppm atau $70.08 \%$. Hal ini menunjukkan bahwa semakin lama waktu kontak maka semakin besar penurunan kadar deterjen yang ada di dalam air. Kemampuan Penyerapan Eceng Gondok Terhadap Amoniak Dalam Limbah Rumah Sakit Berdasarkan Umur dan Lama Waktu Kontak bahwa nilai koefisien korelasi pada penelitian tersebut menunjukkan 0.99811 yang berarti adanya hubungan yang tinggi antara rerata kadar amonia terhadap lama kontak. Sehingga lama kontak mempunyai pengaruh terhadap penurunan zat polutan (Zaman, Badrus dan Endro Sutrisno, 2006). Salah satu

yang mempengaruhi pertumbuhan eceng gondok adalah $\mathrm{pH}$ dan suhu. Syarat pertumbuhan yang optimum bagi eceng gondok adalah $\mathrm{pH}$ sekitar 7-7.5 dan suhu antara $20-30^{\circ} \mathrm{C}$ (Ratnani, dkk, 2010). Dalam penelitian ini $\mathrm{pH}$ terendah 6.1 dan tertinggi 6.7 maka tidak sesuai dengan syarat pertumbuhan eceng gondok. $\mathrm{pH}$ yang tidak memenuhi syarat maka akan mempengaruhi pertumbuhan eceng gondok. Dan nilai $\mathrm{pH}$ setiap harinya juga mengalami perubahan seperti kenaikan ataupun penurunan. Kenaikan maupun penurunan nilai $\mathrm{pH}$ selama proses fitoremediasi disebabkan oleh aktivitas biokimia mikroorganisme yang terdapat pada air limbah dan pada akar tanaman eceng gondok. Sedangkan suhu dalam 
penelitian ini terendah adalah $27^{\circ} \mathrm{C}$ dan tertinggi adalah $30^{\circ} \mathrm{C}$ maka masih sesuai dengan syarat pertumbuhan eceng gondok (Sitompul, dkk, 2013). Setiap harinya suhu juga mengalami perubahan angka. Hal ini terjadi dikarenakan adanya perubahan cuaca selama penelitian.

3. Persentase Penurunan Kadar Deterjen Berdasarkan Jumlah Eceng Gondok

Karena kadar deterjen awal yang terlalu tinggi menyebabkan kelayuan pada tanaman eceng gondok. Kelayuan yang terjadi pada tanaman eceng gondok dikarenakan, deterjen dapat menyebabkan penghambatan pertumbuhan pada tumbuhan dan ikan, menyebabkan kerusakan insang ikan. Surfaktan juga berpengaruh toksik secara akut pada makhluk perairan (Switarto, Bambang, 2012). Konsentrasi awal $200 \mathrm{mg} / \mathrm{l}$, eceng gondok dapat menurunkan kadar fosfat sampai $24.03 \%$. Efisiensi penurunan ini semakin berkurang pada konsentrasi awal $250 \mathrm{mg} / \mathrm{l}$ efisiensi penurunannya $22.95 \%$ dan pada konsentrasi $300 \mathrm{mg} / \mathrm{l}$ menjadi $20.87 \%$. Waktu pemaparan berpengaruh signifikan terhadap efisiensi penurunan fosfat oleh eceng gondok (Prihandrijanti, Maria, 2009). Dari penelitian diatas dapat disimpulkan bahwa semakin tinggi konsentrasi awal yang diberikan, maka semakin rendah penyerapan yang dilakukan eceng gondok untuk menurunkan kadar fosfat. Dari pernyataan tersebut dapat dijadikan acuan terhadap penambahan deterjen dalam menentukan kadar deterjen awal untuk penelitian selanjutnya.

Kerapatan tanaman berpengaruh terhadap penurunan konsentrasi logam. Semakin tinggi tingkat kerapatan tanaman maka semakin kecil pula konsentrasi logam. Ini disebabkan karena kandungan logam pada limbah cair telah diserap oleh akar tanaman eceng gondok dengan kerapatan yang berbeda (Hartanti, Putri Indah, 2013:33). Ditinjau dari tabel IV.6 dengan menggunakan 2 eceng gondok persentase penurunan kadar deterjen sebesar $4.84 \%$. Penurunan kadar deterjen menggunakan 4 eceng gondok sebesar $9.56 \%$ dan menggunakan 6 eceng gondok persentase penurunan kadar deterjen semakin besar menjadi $70.08 \%$. Dalam penelitian ini menunjukkan bahwa semakin banyak tanaman eceng gondok yang digunakan, maka semakin besar pula persentase penurunan kadar deterjennya. Hal ini juga dibuktikan pada penelitian bahwa pada variasi kerapatan yang berbeda, dihasilkan efisiensi penurunan konsentrasi LAS dan minyak lemak yang berbeda (Prihandrijanti, Maria, 2009). Maka pada kerapatan yang lebih tinggi, efisiensi penurunannya semakin besar. Sehingga dengan menggunakan 6 eceng gondok dapat dimanfaatkan untuk menurunkan kadar deterjen awal yang tinggi menjadi ramah terhadap lingkungan. Hal ini dapat membuktikan bahwa eceng gondok adalah merupakan tanaman yang bermanfaat untuk mereduksi limbah (Ratnani, dkk, 2010).

\section{KESIMPULAN}

Kadar deterjen sebelum diberi eceng gondok berdasarkan waktu kontak menunjukkan penurunan kadar deterjen sebesar $0.09 \mathrm{ppm}, 0.07 \mathrm{ppm}$ dan $0.21 \mathrm{ppm}$ dengan bertambahnya waktu kontak. Sedangkan kadar deterjen setelah diberi eceng gondok menunjukkan bahwa semakin banyak eceng gondok dan semakin lama waktu kontak maka penurunan kadar deterjen semakin besar yang ditunjukkan pada hari ke-6 dengan menggunakan 6 eceng gondok kadar deterjen menurun sebesar $47.06 \mathrm{ppm}$ atau $70.08 \%$. Sehingga dikatakan eceng gondok memiliki manfaat atau eceng gondok mampu dalam menurunkan kadar deterjen.

\section{SARAN}

Saran untuk perusahaan pengolah air baku, dapat memanfaatkan tanaman eceng gondok dalam menurunkan kadar deterjen di dalam air. Sedangkan saran untuk peneliti lain, dapat menambah jumlah tanaman eceng dan memperpanjang waktu kontak dengan melakukan proses pengolahan yang sama. Jika menggunakan penambahan deterjen sebaiknya memperhitungkan kadar deterjen awal.

\section{DAFTAR PUSTAKA}

Gumilang, Guslan, 2014. Limbah Detergen Cemari Pesisir. http://www.jawapos.com/baca/artik el/7947/Limbah-Detergen-CemariPesisir. Diakses pada tanggal 22 Desember 2014 pukul 11.03 WIB 
Kusnan, 2012. Evaluasi Kejadian Sedimentasi di Kali Surabaya, Sebagai Data Penunjang Untuk Mengantisifasi Terjadinya Banjir di Kota Surabaya. http://jurnalpengairan.ub.ac.id.

Diakses pada tanggal 18 Februari 2015 pukul 13.25 WIB

Lestari, Sri, Devi Nuraini Santi dan Indra Chahaya, 2012. Pemanfaatan Serbuk Eceng Gondok Untuk Menurunkan Kadar Kadmium (Cd) Pada Air Sumur Gali Masyarakat Di Desa Namo Bintang Kecamatan Pancur Batu KabupatenDeli Serdang Tahun

2012.http://download.portalgaruda. orq/article.php. Diakses pada tanggal 29 Oktober 2014 pukul 11.14 WIB

Prihandrijanti, Maria, 2009. Fitoremediasi Dengan Enceng Gondok dan Kiambang Untuk /Menurunkan Konsentrasi Deterjen, Minyak Lemak dan Krom Total. http://scribd.com. Diakses pada tanggal 13 Juli 2015 pukul 21.05 WIB

Putera, Rizky Dirga Harya, 2012. Ekstrasi Serat Selulosa Dari Tanaman Eceng Gondok (Eichornia Crassipes) Dengan Variasi Pelarut.http://lib.ui.ac.id/file?file=di gital/20313262-S43696-

Ekstraksi\%20serat.pdf. Diakses pada tanggal 18 Desember 2014 pukul 09.31 WIB

Ratnani, Dwi Rita, Indah Hartanti dan Laeli Kurniasari, 2010. Pemanfaatan Eceng Gondok (Eichornia Crassipes) Untuk Menurunkan Kandungan COD (Chemical Oxygen Demond), $\mathrm{pH}$, Bau Dan Warna Pada Limbah Cair Tahu.

http://www.academia.edu/8740192 837-1796-1-SM. Diakses pada tanggal 22 Desember 2014 pukul 09.45 WIB

Sitompul, Debora F., Mumu Sutisna dan Kancitra Pharmawati, 2013. Pengolahan Limbah Cair Hotel Aston Braga City Walk dengan Proses Fitoremediasi menggunakan Tumbuhan eceng Gondok. http://ejurnal.itenas.ac.id. Diakses pada tanggal 28 Januari 2015 pukul 14.24 WIB

Switarto, Bambang dan Sugito, 2012. Aplikasi Biofilter Aerobik Untuk Menurunkan Kandungan Detergen Pada Air Limbah Laundry. http://digilib.unipasby.ac.id. Diakses pada tanggal 24 Juni 2015 pukul 12.12 WIB

Yunarsih, Ni Made, 2013. Efektifitas Membran Khitosan Dari Kulit Udang Galah (Macrobanchium Rosenbergii) Untuk MenurunkanFosfat Dalam Air Limbah Laundry. http://www.pps.unud.ac.id/thesis/p df thesis/unud-807-1318806460tesis\%20yunarsih\%20jadi.pdf. Diakses pada tanggal 22 Desember 2014 pukul 12.28 WIB

Zaman, Badrus dan Endro Sutrisno, 2006. Kemampuan Penyerapan Eceng Gondok Terhadap Amoniak Dalam Limbah Rumah Sakit Berdasarkan Umur dan Lama Kontak (Studi Kasus: RS Panti Wilasa, Semarang). http//eprints.undip.ac.id.pdf.

Diakses pada tanggal 7 Mei 2015 pukul 20.29 WIB 